\title{
A RASCH ANALYSIS ON TOURISM BUSINESS IN COVID-19 ERA: THE ATTACTIVENESS OF TAMAN MINI INDONESIA INDAH (TMII) JAKARTA
}

\author{
Erma Lusia \\ Tourism Department, Faculty of Economics and Communication \\ Bina Nusantara University Jakarta, Indonesia \\ Email: ermalusia@binus.edu \\ Maria Grace Herlina \\ Management Department, BINUS Business School Undergraduate Program, Bina \\ Nusantara University Jakarta, Indonesia \\ Email: herlina01@binus.edu
}

\begin{abstract}
The SARS-CoV-2 pandemic impacts health, the economy, and the environment (also known as COVID19). It's no secret that tourism has been hit particularly hard during the Covid-19 era. Nevertheless, many people continue to search for a tourist destination despite the covid-19 health protocol. Individuals tend to stay home during an outbreak, and large families with young children travel shorter distances than other tourist groups. Local visitors continue to be interested in TMII as a domestic tourism destination as 74 percent of visitors want to visit TMII. Analysis of TMII's amenities and ancillary services using the Rasch Model revealed the most attractive destination attributes. However, when it comes to transportation options, they are by far the least appealing.
\end{abstract}

\section{Keywords: Human Resource Planning, SWOT Analysis}

Received: 23 August 2021 ;

Accepted: 21 December 2021 ;

Publish: December 2021

\section{How to Cite:}

Lusia, E, \& Herlina, M.G. (2021). A Rasch Analysis on Tourism Business in Covid19 Era: The Attactiveness of Taman Mini Indonesia Indah (TMII) Jakarta. Journal of Business and Behavioural Entrepreneurship, 5(2), 87-98. https://doi.org/10.21009/ JOBBE.005.2.11 


\section{INTRODUCTION}

The World Health Organization for COVID-19 has officially declared a global pandemic as of January 2020. Deaths and infections linked to COVID-19 are rising, and many countries have implemented travel bans, quarantines, and curfews (Sohn et al., 2021). As a result of the SARS-CoV-2 pandemic (also known as COVID19), health, economics, and the environment are all affected. Most of these impacts are negative, but there have been some positive outcomes in specific fields. Tourism was one of the worst-hit industries (Monteiro et al., 2021). Travel and tourism numbers have plummeted as the COVID-19 pandemic unfolds. Due to 166 countries restricting entry into their national territories, global mobility has come to a near standstill, leaving tourism destinations empty-handed because their primary resource, mobile tourists, is effectively absent (Lapointe, 2020). Tourism has been halted worldwide due to the COVID-19 outbreak, which has restricted international travel. As a result, travel demand has shifted away from international destinations and toward domestic ones. Global tourism has suffered due to a long-term ban on the journey that has altered travel trends and behaviors (Sohn et al., 2021). Global tourism expected to decline by around 80 percent by 2020 due to the coronavirus (COVID-19) pandemic. Travel within the country is helping to soften the blow, at least partly, and governments have taken impressive immediate action to restore and reactivate the sector while also protecting jobs and businesses.

Consequently, with the resumption of domestic tourism, some destinations have seen a reduction in the loss of jobs and revenue. Proper recovery will only be possible once international tourism returns. Tourism in the domestic level is expected to grow, as people prefer to stay at home and travel to places within their own nation. Domestic tourists tend to be more price-conscious and spend less (OECD, 2020).

Using the prefix "un" and the word "contact," the term "untact" refers to the Korean version of social distancing. After the COVID-19 travel restrictions, the term became popular in Korea to describe the significant shift in people's unwillingness to interact with others (i.e., contact-free society) as a result of infections. It means that the current tourism trend that COVID-19 has reshaped characterized by unrestrained and short-distance travel. Many people chose to visit a destination near their home after the COVID-19 outbreak over a large and famous destination away (Sohn et al., 2021). Safety and hygienic conditions have become important considerations when choosing travel destinations and activities. Individuals are more likely to travel alone, avoid large crowds and prioritize private transportation, which could negatively impact the environment. The ongoing digitalization of tourism services will include a greater reliance on automation, contactless payment and service options, virtual reality experiences, and real-time information (OECD, 2020). The path to a new normal in the Indonesian tourism sector involves preparing a variety of factors. In addition, it arranges for health care and outdoor activities, workplace and educational services, and business trips, events, and public transportation. Tourism takes on a new meaning when it comes to the environment and human health. If there is a systemized mitigation at the tourist spot, a standard operating procedure, or a system that limits the number of visitors to tourist attractions, is the visitor's health and safety guaranteed, etc., then the visitors will validate that. People tend to travel within their own countries (Dušek \& Sagapova, 2021). On vacation, people are more likely to stay in their own country, and large families with young children are more likely to travel short distances than other travelers. Natural tourism, such as enjoying the beauty of nature, the sea, mountains, and activities in the open air, is something that many tourists look forward to. Most 
tourists prefer to plan their trips, including restaurants and transportation services in their chosen tourist destination (Dušek \& Sagapova, 2021; Yuni, 2020).

The COVID-19 pandemic has had a significant impact on the tourism industry. There has been a dramatic drop in local and foreign tourists since implementing Scaled Social Restrictions (PSBB) and efforts to prevent coronavirus spread. A popular tourist attraction in Indonesia, the Indonesia Miniature Park or Taman Mini Indonesia Indah (TMII), has declined visitors. Before the pandemic, up to 80,000 people visited TMII every weekend; after the pandemic, the average weekend visitor is less than 10,000 people. As long as TMII is open during PSBB-Transition, there will be many rule changes, operational hours, and health protocol implementation. A tourist attraction located in East Jakarta, TMII has implemented changes to both its officers' and visitors' behavior to adapt to the New Normal or a new life as a tourist attraction (Relations-jpr, 2020).

The government formed a COVID-19 Prevention and Economic Recovery National team to deal with the outbreak. As a result, some tourist attractions have been allowed to reopen to visitors with a few restrictions, such as implementing COVID-19 health protocols, such as checking body temperature, wearing masks, providing a place to wash hands and hand sanitizers well as a 25 percent capacity limit. There is a twopart program to open a tourist attraction at TMII that follows government policies to recover the tourism industry. Preparing the CHS health protocol (cleanliness, health, and safety are the primary concern of TMII management. Began in October 2020, tourism destinations are allowed to open gradually but with strict health protocols. It includes online ticketing where visitors can purchase the entry ticket on the TMII website. Visitors can make online reservations at any time and from any location, and visitors can also take advantage of a promotional package on the website. Next, they are spraying disinfectant at the entrance of TMII, wearing a mask, providing handwashing stations at various locations in the TMII area, and providing hand sanitizer to visitors. Also, a health check is performed every time visitors enter a particular traditional house pavilion or attraction area (Relations-jpr, 2020). The research will look at the attractiveness of a local tourist destination in terms of its ability to support the tourism businesses recovery. Many studies on tourist destinations have been conducted, but this study differs from others since conducted in a new normal era and using Rasch Model approach to analyze the research data.

\section{LITERATURE REVIEW}

Most people prefer to stay in their own country when on vacation, and large families with young children travel short distances. Numerous tourists look forward to experiencing nature, the sea, mountains, and outdoor activities in the open air. Visitors prefer to plan their vacations, including restaurants and transportation services in their chosen tourist destinations (Dušek \& Sagapova, 2021; Yuni, 2020).

A tourism product encompasses the entire experience, from the moment they leave their home to when they arrive back home again. Tourists perceive and enjoy tourism products as a whole, according to the tourism expert. Attraction, transportation, accommodation, support and auxiliary services, and physical and communication infrastructure make up the five components of tourism quality. According to a different researcher, there are five types of tourism products: attraction of destination and environment, destination and service facilities, accessibility in the destination area, destination image, and price. Based on the scholar's opinions, the dimensions of a destination attractiveness are accessibility, amenities, attractive activities, ancillary service 
(Fedorko, 2019; Kerdpitak, 2019; Lanzara \& Minerva, 2019; Law \& Law, 2021; Robustin et al., 2018; Yuni, 2020).

Accessibility quality defines destinations' ability to provide quality transportation methods that facilitate the transfer of people from one place to another. Besides, accessibility, affordability, and convenience of tourism transportation infrastructure will enhance the accessibility quality and tend to improve the success of a tourism destination (Law \& Law, 2021; Tomej \& Liburd, 2020). Furthermore, previous research proved that accessibility quality would increase the visitors' satisfaction and revisit intention to the tourism destination (Hooper, 2015; Law \& Law, 2021; Tomej \& Liburd, 2020).

Today's travelers are looking for quality and value, and they are much more confident in making decisions and rely on other travelers instead of traditional forms of advertising for guidance. Destination's reputation reflects its perceived value, product quality, service quality, social activity, and reputation on the internet. Complimentary services such as free WiFi, smoke-free property, and multilingual staff will influence customers' ratings and willingness to recommend tourism destinations (Fedorko, 2019). Accommodation, cleanliness, and hospitality are all examples of amenities that can gain pleasure from a product (tangible and intangible products). Many facilities are required to meet the needs of tourists, including transportation and lodging facilities and food-and-drink services. Neither this nor the infrastructure component, which ensures the availability of full facilities, can be separated (Robustin et al., 2018). Previous studies show that amenities and ancillary service can improve the destination's reputation and recommendation to improve revisited intention to the tourism destination (Hanna et al., 2019; Kerdpitak, 2019; Robustin et al., 2018; Winter et al., 2020).

The scholars explain that the tourism destination should have recreational, educational, adventure, eco-tourism, meeting relatives and friends (Kerdpitak, 2019). Previous studies prove that tourism destination activities can influence tourists' preferences and experiences (Aşan \& Emeksiz, 2018; Hanna et al., 2019; Kerdpitak, 2019; Winter et al., 2020).

Taman Mini Indonesia Indah (TMII) is a tourist destination that offers various activities, including recreational, educational, and eco-tourism activities (Kerdpitak, 2019). To achieve a new normal in tourism, Indonesian attractions managers must prepare health protocols and outdoor activities. (Yuni, 2020). Therefore TMII as a domestic tourism destination in Jakarta, Indonesia will be evaluated based on its tourism destination attributes. The dimensions of attractiveness are accessibility, amenities, tourism activities, and ancillary service (Miftahuddin et al., 2020), 2020). Since tourism activities can improve mental health and well-being, it is beneficial to examine TMII based on accessibility and amenities and engaging activities in the Covid-19 Era.

\section{RESEARCH METHODS}

The research examines Taman Mini Indonesia Indah (TMII), one of the domestic tourism destinations in Jakarta, Indonesia, in the Covid-19 Era. To collect the primary data, a researcher used a questionnaire. Only 336 respondents can examine further from 368 respondent who has visited TMII. The respondent's characteristics are $43 \%$ male and $57 \%$ female. The age of respondents is $72 \%$ more than 21 years old and $28 \%$ less than 21 years old. At the same time, the education level is $60 \%$ high school graduates, $6 \%$ diploma graduates, $28 \%$ bachelor degree graduates, and $6 \%$ master degree graduates. Also, their jobs are $40 \%$ are students, $8 \%$ civil servants, $37 \%$ private employees, $10 \%$ are entrepreneurs, $5 \%$ are housewives. 
The research is quantitative research without experimental designs. The research data were collected using questionnaires based on the literature review. In addition, the researchers used social media to collect the data through online questionnaires such as WhatsApp group, Facebook, telegram, and others. Research variables will be analyzed using the Rasch Model with the application of Winstep software version 3.73, including the validity and the reliability test of the questionnaire.

Rasch Model Analysis is a method that allows ordinal data from Likert Rating scales questionnaires to be converted into interval data (Miftahuddin et al., 2020). The Rasch model is the most appropriate method for quantitative analysis in human sciences since the research instruments used will produce ordinal data. According to the measurement model, Rasch model analysis is based on the probability that allows respondents' responses to be accurately predicted on all items. The Rasch Model changes the item scores measured on a Likert rating scale, an ordinal data, into an interval scale called "unit of opportunity logarithms" (logit). Rasch Model Analysis can also reduce the invalid responses of the self-report questionnaire (Miftahuddin et al., 2020).

The research instrument developed represents the destination attractiveness, which has four dimensions with thirty indicators. Those items are statements on the research instrument. Before collecting the data, the items on the research instruments were tested using Rasch Model Analysis with Winstep software version 3.73. The first examination was the research instrument's validity, and reliability tested-table 1 shows the reliability test results.

Table 1 Reliability Test of The Destination Attractiveness Instrument

\begin{tabular}{|c|c|c|}
\hline $\begin{array}{c}\text { Statistics Sum- } \\
\text { mary }\end{array}$ & Person & Item \\
\hline Reliability & 0.89 & 0.96 \\
\hline Cronbach Alpha & \multicolumn{2}{|c|}{0.91} \\
\hline
\end{tabular}

Table 1 shows that the Cronbach Alpha of the instrument reliability as a whole is 0.91 , meaning that there is excellent interaction between the items and the respondents' responses (Sumintono, 2014). Next, the person reliability is 0.89 implies the consistency of the respondents' answers is excellent, and the item reliability is 0.96 , meaning that the research instrument's items are also outstanding. Both values indicate a firm consistency in respondents' responses, and the quality of the items is excellent to measure the destination attractiveness (Sumintono, 2014).

The next test is about the validity of the item of the research instruments. The research instrument was created based on the literature review. There are four dimensions of destination attractiveness consist of thirty indicators as mentioned in Table 2. 


\section{Table 2 The Destination Attractiveness Dimensions and Indicators}

\begin{tabular}{|c|c|c|}
\hline Construct & Item & Code \\
\hline \multirow{5}{*}{ Accessibility } & TMII's location is close to the city center. & $\mathrm{AC} 1$ \\
\hline & The location of TMII is easy to reach. & $\mathrm{AC} 2$ \\
\hline & $\begin{array}{l}\text { There are many choices of vehicles to } \\
\text { TMII. }\end{array}$ & $\mathrm{AC} 3$ \\
\hline & $\begin{array}{l}\text { Infrastructure to get to TMII can support } \\
\text { visitors to come back. }\end{array}$ & $\mathrm{AC4}$ \\
\hline & $\begin{array}{l}\text { The location of TMII is accessible for disa- } \\
\text { bilities and elderly. }\end{array}$ & $\mathrm{AC5}$ \\
\hline \multirow{6}{*}{ Amenities } & TMII tourist location is clean. & AM1 \\
\hline & $\begin{array}{l}\text { The bicycle and motorbike rentals to get } \\
\text { around TMII. }\end{array}$ & AM2 \\
\hline & Information services for visitors. & AM3 \\
\hline & Spacious parking area for visitors & AM4 \\
\hline & Restroom facilities are clean. & AM5 \\
\hline & The Culinary facilities are clean. & AM6 \\
\hline \multirow{7}{*}{$\begin{array}{l}\text { Attractive } \\
\text { Actitivities }\end{array}$} & $\begin{array}{l}\text { Sitting relaxing with family in open air tra- } \\
\text { ditional houses in TMII. }\end{array}$ & AT1 \\
\hline & Visiting museums at TMII & AT2 \\
\hline & Shopping for souvenirs at TMII. & AT3 \\
\hline & Cycling in the open air around TMII. & AT4 \\
\hline & Culinary in the open air restaurants at TMII. & AT5 \\
\hline & Riding the open air cable car at TMII & AT6 \\
\hline & Riding an open air tourist train at TMII & AT7 \\
\hline \multirow{5}{*}{$\begin{array}{l}\text { Ancillary Ser- } \\
\text { vice }\end{array}$} & Tour guides for visitors & AN1 \\
\hline & Bank and ATM services for visitors & AN2 \\
\hline & Various types of souvenir shops at TMII. & AN3 \\
\hline & Places of worship for visitors & AN4 \\
\hline & Health services for visitors & AN5 \\
\hline
\end{tabular}

The research instrument validity was tested using MISFIT ITEM. The validity test results show no outliers since the logit values are above 0.5 logit and below 1.5 logit (Sumintono, 2014); therefore, all items can be indicators in the research instrument, as presented in Table 3. 
Table 3 Item Validity of The Destination Attractiveness

\begin{tabular}{|c|c|c|c|c|c|c|c|}
\hline $\begin{array}{c}\text { Item } \\
\text { s }\end{array}$ & $\begin{array}{c}\text { OUT- } \\
\text { FIT } \\
\text { MNSQ } \\
\text { (logit) }\end{array}$ & $\begin{array}{c}\text { Item } \\
\text { s }\end{array}$ & $\begin{array}{c}\text { OUT- } \\
\text { FIT } \\
\text { MNSQ } \\
\text { (logit) }\end{array}$ & $\begin{array}{c}\text { Item } \\
\text { s }\end{array}$ & $\begin{array}{c}\text { OUT- } \\
\text { FIT } \\
\text { MNSQ } \\
\text { (logit) }\end{array}$ & $\begin{array}{c}\text { Item } \\
\text { s }\end{array}$ & $\begin{array}{c}\text { OUT- } \\
\text { FIT } \\
\text { MNSQ } \\
\text { (logit) }\end{array}$ \\
\hline AC1 & 1.19 & AM1 & 0.82 & AT1 & 1.01 & AN1 & 1.00 \\
\hline AC2 & 1.32 & AM2 & 0.83 & AT2 & 1.10 & AN2 & 1.08 \\
\hline AC3 & 1.28 & AM3 & 0.89 & AT3 & 0.99 & AN3 & 0.88 \\
\hline AC4 & 0.84 & AM4 & 1.08 & AT4 & 0.96 & AN4 & 1.11 \\
\hline AC5 & 0.94 & AM5 & 0.87 & AT5 & 0.85 & AN5 & 1.29 \\
\hline & & AM6 & 0.71 & AT6 & 1.10 & & \\
\hline & & & & AT7 & 0.85 & & \\
\hline
\end{tabular}

Source: Primary Research Data, 2020

\section{RESULTS AND DISCUSSIONS}

First, the researchers will examine the number of attracted visitors to TMII using a wright map resulting from Rasch Analysis. The wright map (figure 1) shows that TMII visitors who are highly attracted are $8 \%$ visitors, $12 \%$ visitors are more attracted, and $59 \%$ visitors are attracted. While $12 \%$ of visitors are only moderately attracted, $14 \%$ are less attracted, and only 0.1 percent are the least attracted to TMII.

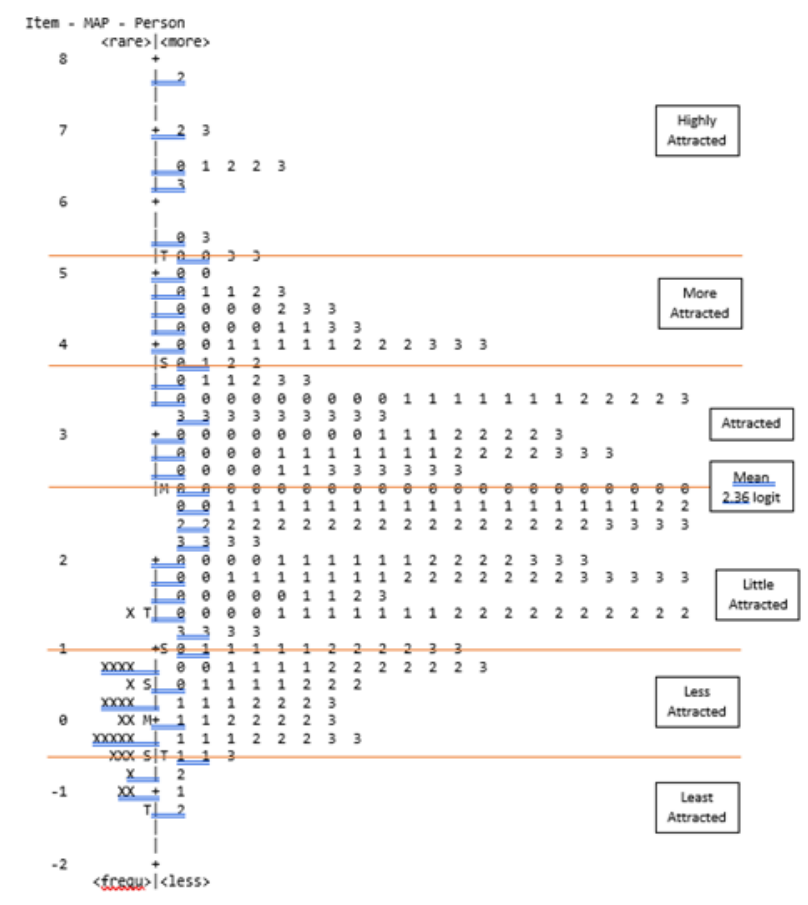

A Rasch Analysis on Tourism Business in Covid-19 Era: The Attactiveness of Taman Mini Indonesia Indah (TMII) Jakarta. 


\section{Figure 1 The Wright Map of The Visitors' Attractiveness}

It implies that TMII as a domestic tourism destination still has its attractiveness to the local visitors during the covid-19 era since $74 \%$ of visitors are still attracted to TMII.

A deeper analysis using Rasch Model, as shown in Table 4, reveals that the tour guide (AN1) is the most attractive attribute for TMII as a tourism destination, while transportation options to get there is the least attractive attribute (AC3). Although TMII is located in the Greater Jakarta area, visiting TMII remains a challenging tourist destination for the visitors. More TMII attractions for visitors are shown on the wright map of the tourism destination's attractiveness (Figure 2), and the detailed analysis is in table 4.

Table 4 The Most Attractive to The Least Attractive of The Destination

\begin{tabular}{|c|c|c|c|c|c|c|c|}
\hline Items & $\begin{array}{c}\text { OUTFIT } \\
\text { MNSQ } \\
\text { (logit) }\end{array}$ & Items & $\begin{array}{c}\text { OUTFIT } \\
\text { MNSQ } \\
\text { (logit) }\end{array}$ & Items & $\begin{array}{c}\text { OUTFIT } \\
\text { MNSQ } \\
\text { (logit) }\end{array}$ & Items & $\begin{array}{c}\text { OUTFIT } \\
\text { MNSQ } \\
\text { (logit) }\end{array}$ \\
\hline AC3 & 1.13 & AM1 & 0.31 & AT6 & -0.17 & AC5 & -0.55 \\
\hline AT3 & 0.84 & AC2 & 0.25 & AM3 & -0.18 & AN3 & -0.59 \\
\hline AT1 & 0.83 & AN2 & 0.22 & AM6 & -0.25 & AM5 & -0.86 \\
\hline AM4 & 0.78 & AM2 & 0.14 & AT4 & -0.28 & AN5 & -0.93 \\
\hline AC4 & 0.65 & AT7 & 0.07 & AT5 & -0.32 & AN1 & -0.97 \\
\hline AN4 & 0.53 & AC1 & -0.09 & AT2 & -0.54 & & \\
\hline & & & & & & & \\
\hline
\end{tabular}

Source: Primary Research Data, 2020

The wright map of destination attractiveness (figure 2) shows four categories of attractiveness as summarized in table 5. It indicates that ancillary services and amenities are the most attractive attributes of a tourism destination at TMII.

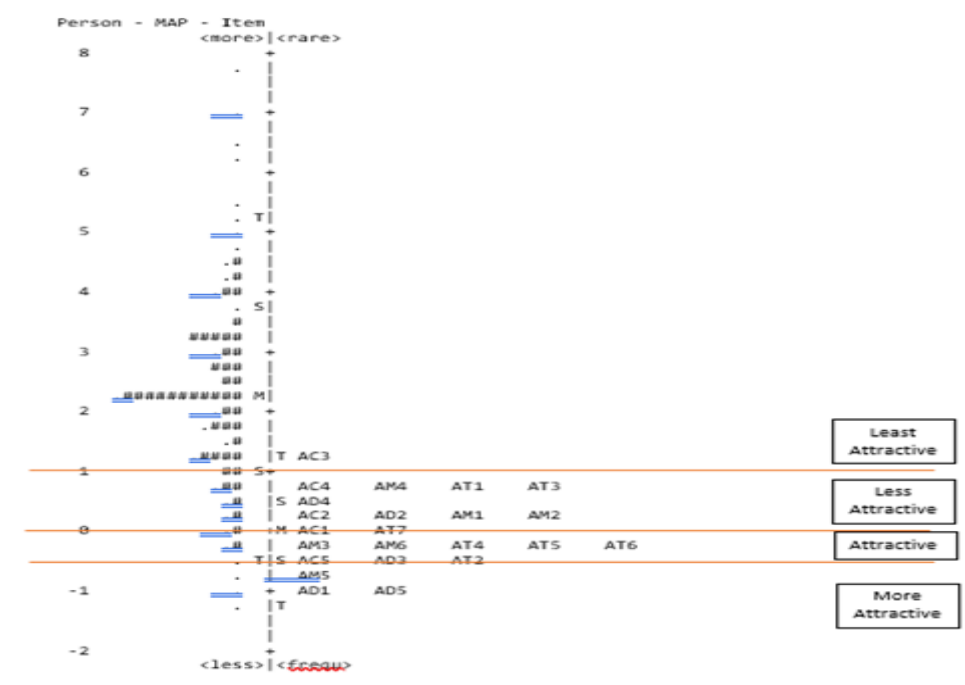

A Rasch Analysis on Tourism Business in Covid-19 Era: The Attactiveness of Taman Mini Indonesia Indah (TMII) Jakarta. 


\section{Figure 2 The Wright Map of The Destination Attractiveness}

Based on the Rasch Model analysis, TMII's most attractive attributes include tour guides, health services for visitors, and clean restrooms. Those attributes explain that the cleanliness of tourism destinations and health is the primary concern for the visitors. The most attractive feature is a tour guide. It infers that a tour guide's role is vital for visitors to TMII's vast area, and in this pandemic era, tour guides can also help maintain the health protocol during the visit. It is also possible for tour guides to limit the number of visitors brought into a single group. Tour guides can also show visitors where to find health services during a pandemic because the TMII management must keep visitors healthy when finding leisure during the outbreak.

The research result can support the previous researches about ancillary services and amenities. Furthermore, the studies show that amenities and ancillary service can improve the destination's reputation and recommendation to improve revisited intention to the tourism destination (Hanna et al., 2019; Kerdpitak, 2019; Robustin et al., 2018; Winter et al., 2020).

\section{Table 5 Summary of The Destination Attractiveness}

\begin{tabular}{|c|c|c|}
\hline Construct & Item & Code \\
\hline \multirow{3}{*}{ More Attractive } & Tour guides for visitors & AN1 \\
\hline & Health services for visitors & AN5 \\
\hline & Restroom facilities are clean. & AM5 \\
\hline \multirow{10}{*}{ Attractive } & Various types of souvenir shops at TMII. & AN3 \\
\hline & The location of TMII is accessible for disabilities and elderly. & $\mathrm{AC5}$ \\
\hline & Visiting museums at TMII & AT2 \\
\hline & Culinary in the open air restaurants at TMII. & AT5 \\
\hline & Cycling in the open air around TMII. & AT4 \\
\hline & The Culinary facilities are clean. & AM6 \\
\hline & Information services for visitors. & AM3 \\
\hline & Riding the open air cable car at TMII & AT6 \\
\hline & TMII's location is close to the city center. & $\mathrm{AC} 1$ \\
\hline & Riding an open air tourist train at TMII & AT7 \\
\hline \multirow{9}{*}{ Less Attractive } & Shopping for souvenirs at TMII. & AT3 \\
\hline & $\begin{array}{l}\text { Sitting relaxing with family in open air traditional houses in } \\
\text { TMII. }\end{array}$ & AT1 \\
\hline & Spacious parking area for visitors & $\overline{\mathrm{AM} 4}$ \\
\hline & Infrastructure to get to TMII can support visitors to come back. & $\overline{\mathrm{AC} 4}$ \\
\hline & Places of worship for visitors & $\overline{\mathrm{AN} 4}$ \\
\hline & TMII tourist location is clean. & AM1 \\
\hline & The location of TMII is easy to reach. & $\mathrm{AC} 2$ \\
\hline & Bank and ATM services for visitors & AN2 \\
\hline & The bicycle and motorbike rentals to get around TMII. & AM2 \\
\hline Least Attractive & There are many choices of vehicles to TMII. & $\mathrm{AC3}$ \\
\hline
\end{tabular}

A Rasch Analysis on Tourism Business in Covid-19 Era: The Attactiveness of Taman Mini Indonesia 
TMII's transportation options, on the other hand, remain the least appealing to visitors. Many people are still afraid to use public transportation because of the covid19 era, and as a result, the options for visitors who use public transportation are severely limited.

\section{CONCLUSIONS}

Health, economics, and the environment are all affected by the SARS-CoV-2 pandemic (also known as COVID19). Tourism was one of the worst-hit industries during the covid-19 era. Since tourism activities can improve mental health and wellbeing, people are still searching for the tourism destination without neglecting the covid-19 health protocol. During the outbreak, people are more likely to stay in their own country, and large families with young children are more likely to travel short distances than other tourists. Therefore, TMII as a domestic tourism destination remains attractive to local visitors as $74 \%$ of visitors are still interested in visiting TMII.

As a result of the research, TMII's amenities and ancillary services are the most attractive destination attributes. TMII's management appears to prioritize visitors' health, as tour guides, health services, and clean restrooms are the most appealing indicators. TMII can also provide a sanitizer set and masks to those who have paid for entrance tickets to bolster those destination qualities. Even though TMII is located in a highly accessible area, transportation options are the least appealing feature. Visitor safety and security may be improved by partnering with online transportation service providers. Visitors can order online transportation that has partnered with TMII to pick them up from home back and forth to improve the health protection of TMII visitors. There are still some limitations to this study. The research instruments should be rearranged with more items to measure each tourism attraction's dimensions for further research. It is also preferable to include more respondents from diverse backgrounds and to use inferential statistics to examine the influence of each attribute that can contribute to the attractiveness of a tourism destination.

\section{ACKNOWLEDGEMENT}

We want to express our gratitude and appreciation to Mr Bambang Sumintono, PhD, who taught us about Rasch Model Analysis and gave us opportunities to practice more using the Winstep software version 3.73 in Rasch Model Analysis.

\section{REFERENCES}

Aşan, K., \& Emeksiz, M. (2018). Outdoor recreation participants' motivations, experiences and vacation activity preferences. Journal of Vacation Marketing, 24(1), 315. https://doi.org/10.1177/1356766716676300

Dušek, R., \& Sagapova, N. (2021). Effect of the COVID-19 global pandemic on tourists' preferences and marketing mix of accommodation facilities - case study from Czech Republic. SHS Web of Conferences, 92, 01009. https://doi.org/10.1051/ shsconf/20219201009

Fedorko, R. (2019). Impact of ancillary services on the hotel rating in Visegrad group countries. Marketing and Management of Innovations, 2(June), 99-107. https:// doi.org/10.21272/mmi.2019.2-09

Hanna, P., Wijesinghe, S., Paliatsos, I., Walker, C., Adams, M., \& Kimbu, A. (2019). Active engagement with nature: outdoor adventure tourism, sustainability and 
well-being. Journal of Sustainable Tourism, 27(9), 1355-1373. https:// doi.org/10.1080/09669582.2019.1621883

Hooper, J. (2015). A destination too far? Modelling destination accessibility and distance decay in tourism. GeoJournal, 80(1), 33-46. https://doi.org/10.1007/s10708 $-014-9536-\mathrm{Z}$

Kerdpitak, C. (2019). The influence of destination attributes on the MICE tourism industry in Bangkok, Thailand. International Journal of Innovation, Creativity and Change, 10(1), 76-98.

Lanzara, G., \& Minerva, G. A. (2019). Tourism, amenities, and welfare in an urban setting. Journal of Regional Science, 59(3), 452-479. https://doi.org/10.1111/ jors. 12440

Lapointe, D. (2020). Reconnecting tourism after COVID-19: the paradox of alterity in tourism areas. Tourism Geographies, 22(3), 633-638. https:// doi.org/10.1080/14616688.2020.1762115

Law, F., \& Law, F. (2021). The Impact of Accessibility Quality a nd Accommodation Quality o n Tourists' Satisfaction Revisit Intention to Rural Tourism Destination i Sarawak: The Moderating Role of Local Communities' Attitude. 2021 (November), 1-12.

Miftahuddin, A., Hermanto, B., Raharja, S. J., \& Chan, A. (2020). City brand attractiveness on tourism using rasch model approach. International Journal of Supply Chain Management, 9(2), 150-156.

Monteiro, A., Eusébio, C., Carneiro, M. J., Madaleno, M., Robaina, M., Rodrigues, V., Gama, C., Relvas, H., Russo, M., Oliveira, K., Lopes, M., \& Borrego, C. (2021). Tourism and air quality during COVID-19 pandemic: Lessons for the future. Sustainability (Switzerland), 13(7). https://doi.org/10.3390/su13073906

OECD. (2020). Rebuilding tourism for the future: COVID-19 policy responses and recovery. OECD Tourism Paper, December, 1-8. http://www.oecd.org/ coronavirus/policy-responses/rebuilding-tourism-for-the-future-covid-19-policyresponses-and-recovery-bced9859/

Relations-jpr, J. P. (2020). Strategi Humas Dalam Menyampaikan Informasi Terkait Eksistensi Taman Mini Indonesia Indah ( TMII ) di Masa Pandemi COVID-19. Jurnal Public Relations-Jpr, 1, 97-101.

Robustin, T. P., Sularso, R. A., Suroso, I., \& Yulisetiarini, D. (2018). The Contribution of Tourist Attraction, Accessibility and Amenities in Creating Tourist Loyalty in Indonesia. GATR Journal of Business and Economics Review, 3(4), 92-98. https://doi.org/10.35609/jber.2018.3.4(3)

Sohn, J. I., Alakshendra, A., Kim, H. J., Kim, K. H., \& Kim, H. D. (2021). Understanding the new characteristics and development strategies of coastal tourism for post-covid-19: A case study in korea. Sustainability (Switzerland), 13(13). https:// doi.org/10.3390/su13137408

Sumintono, B. (2014). RASCH SUMINTONO.pdf.

Tomej, K., \& Liburd, J. J. (2020). Sustainable accessibility in rural destinations: a public transport network approach. Journal of Sustainable Tourism, 28(2), 129-146. https://doi.org/10.1080/09669582.2019.1607359

Winter, P. L., Selin, S., Cerveny, L., \& Bricker, K. (2020). Outdoor recreation, naturebased tourism, and sustainability. Sustainability (Switzerland), 12(1), 1-12. https://doi.org/10.3390/SU12010081 
Yuni, L. K. H. K. (2020). Analysis of Domestic Tourist Travel Preferences Post-Covid -19 Pandemic. Journal of Applied Sciences in Travel and Hospitality, 3(2), 8088. https://doi.org/10.31940/jasth.v3i2.2052

A Rasch Analysis on Tourism Business in Covid-19 Era: The Attactiveness of Taman Mini Indonesia Indah (TMII) Jakarta. 